\title{
The Contribution of Principal's Leadership Style, Teacher Competence, and School Climate Toward Students' Learning Outcomes
}

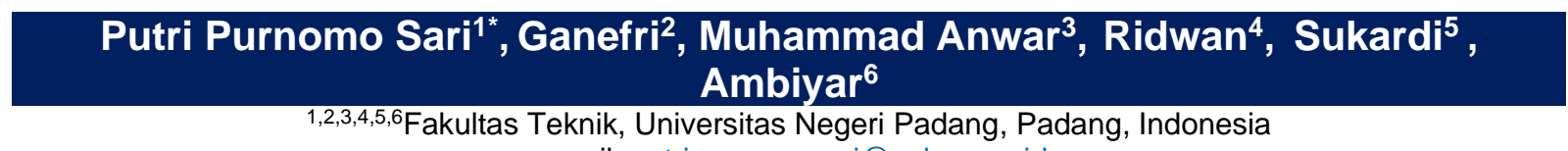 \\ e-mail: putripurnomosari@yahoo.co.id
}

\begin{abstract}
This study aims to analyze the contribution of principal leadership style, teacher competence, and school climates to the quality of learning outcomes. This study was a quantitative method. Data collection was carried out using a questionnaire and analyzed by multiple linear regression. The results of this study are the relationship between the principal's leadership style and the school climate has $t$ count 7.15>t-table 1.96; the relationship between teacher competence and school climates has a value of $t$-count 3.66>t-table 1.96; the relationship between the principal's leadership style and the quality of learning outcomes has t-count 8.13>t-table 1.96; the relationship of teacher competence with the quality of learning outcomes has t-count 5.47>t-table 1.96; the relationship of school climate with the quality of learning outcomes has a t-count value of 5.64>t-table 1.96; the relationship between the principal's leadership style through the school climate with the quality of learning outcomes has a value of $t$-count 4.43>t-table 1.96; the relationship between teacher competence through school climate and the quality of learning outcomes has t-count 3.07>t-table 1.96 .
\end{abstract}

Keywords: Kepala Sekolah, Guru, Hasil Belajar

\section{Introduction}

The quality of learning in schools can be seen from the student learning outcomes obtained. Learning outcomes are still a topic that is very much discussed and analyzed to find out the problems that occur and the appropriate solutions to solve problems regarding learning outcomes. Learning outcomes have the meaning that the results achieved are in the form of numbers or scores after being given a learning outcome test at the end of each lesson. The value obtained by students is a reference to see the mastery of students in receiving subject matter (Aryani, 2014; Lestari, 2018). So, the better the student learning outcomes obtained, the better the quality of learning at the school.

However, based on observations made by researchers on several vocational schools in Padang City, some information was obtained that the quality of learning outcomes at these schools was still low on average. This can be seen from the students' midterm test scores that on average were below the predetermined minimum completeness standard, which was below 75. In addition to low cognitive scores, students also had low scores on the psychomotor aspect. Therefore, researchers are increasingly interested in digging deeper into the causes of the low quality of learning outcomes in several vocational schools in Padang City.

The other problems encountered by researchers in the field are, first, the leadership style used by the principal is not yet in accordance with the characteristics of the environment and the academic community at school. This can be seen from the authoritarian attitude of the principal which causes a less communicative relationship between the principal and the teacher. In addition, the principal's leadership style, which is more concerned with personal opinions than teachers' opinions, is also one of the triggers for various problems in schools. Indirectly has an impact on the teaching and learning process carried out by teachers in the classroom.

\footnotetext{
${ }^{*}$ Corresponding author.

Received 15 April 2020; Accepted 16 August 2020; Available online 01 September 2020 (c) 2020 JPI. All Rights Reserved
} 
Second, the lack of professional attitude that teachers have in carrying out their duties. This can be seen from the number of teachers who do not complete the teaching tools and do not have clear manuals for each subject matter they provide to students. Then there are still many teachers who come to school late, even don't go to school for no apparent reason. Several problems related to the professional competence of teachers have an indirect impact on the learning process and the quality of learning outcomes.

Third, the school climate is less conducive. Many schools are in a crowd, so the teaching and learning process is not carried out optimally. In addition, the relationship between teachers seems less harmonious, where teachers make friends in groups and do not mix with other groups. As well as various other symptoms that researchers may not describe one by one.

Based on the results of these observations, the researcher provides a solution that the quality of learning outcomes is influenced by several factors both internally and externally. In this study the researcher focused on the principal's leadership style, teacher competence and school climate. The first internal factor, namely, the principal who carries out his main tasks in a different style from other school principals, the principal's leadership style is described as the characteristics, habits, temperament, character, and personality that distinguishes a leader in communicating or relating to other people (Djafri, 2015; Muhani et al., 2016). Leadership is a solution for the development and resilience of any organization, be it a company or an institution (Djafar, 2017; Muhani et al., 2016; Yudiaatmaja, 2017). This is particularly important in the provision of education for a real impact on achieving the goals of the school and the achievement of educational goals.

The second internal factor that can affect the quality of learning outcomes is teacher competence. The success of education in each country depends on the teacher being equipped with teacher competence, teacher competence is the teacher's basic ability in knowledge of learning and human behavior, the field of study they teach, appropriate attitudes about the environment and having skills in teaching techniques (Purwanti et al., 2014; Sumantri, 2012). This proves that teacher competence can positively and clearly affect student learning outcomes.

Apart from internal factors, school climate is also an external factor that affects the quality of learning outcomes. School climate is the quality and character of school life, student behavior patterns, the experiences of parents and school employees with school life that reflect norms, goals, values, interpersonal relationships, teaching and learning practices, and organizational structure (Arsil et al., 2018; Hapsari et al., 2014; Sumantri, 2012).

Based on the above problems, it is important to carry out research to determine the relationship between the principal's leadership style and the school climate, the relationship between the principal's leadership style and the quality of learning outcomes, the relationship between teacher competence and the quality of learning outcomes, the relationship between school climate and the quality of learning outcomes, the influence of leadership styles. the principal through the school climate on the quality of learning outcomes, and the influence of teacher competence through the school climate on the quality of learning outcomes in several vocational schools in Padang.

\section{Method}

The kind of this study is quantitative research methods with correlational research. Quantitative research methods are interpreted as research methods based on the philosophy of positivism, used to examine populations or specific samples, collecting data using research instruments, quantitative / statistical data analysis, with the aim to test the hypotheses that have been set (Sugiyono, 2013). While correlational research is research that provides an opportunity to predict certain scores because of the existence of other scores and explain between variables (Creswell, 2008).

The study was conducted at a vocational high school (SMK) in Padang city, West Sumatra. This research was conducted in the even semester of the 2017/2018 school year. The population in this study were all students of class XII in Vocational High Schools (SMK), 
which had quite large variety of majors in Padang city. The samples of this study are 148 persons taken with cluster sampling technique.

The technique to collect the data used questionnaire. The indicators of research variable shown in Table 1.

Tabel 1. Research Variable Indicators

\begin{tabular}{|c|c|c|}
\hline Variable & Indicators & Source \\
\hline $\begin{array}{l}\text { The Quality of } \\
\text { Learning Outcomes }\end{array}$ & Students' test result & Sujana (2004) \\
\hline Principal's & 1. Transformational leadership & Bass (Robbins and \\
\hline $\begin{array}{l}\text { Leadership Style } \\
\left(X_{1}\right)\end{array}$ & $\begin{array}{l}\text { 2. Transactional leadership } \\
\text { 3. Laissez laire leadership }\end{array}$ & Judge, 2015) \\
\hline Teacher & 1. Pedagogical Competence & PP No.19 tahun 2005 \\
\hline Competence $\left(\mathrm{X}_{2}\right)$ & $\begin{array}{l}\text { 2. Personality competence } \\
\text { 3. Professional Competence } \\
\text { 4. Social Competence }\end{array}$ & \\
\hline School Climate $\left(X_{3}\right)$ & $\begin{array}{l}\text { 1. Teacher's behavior } \\
\text { 2. Principal's behavior } \\
\text { 3. The teacher feels comfortable } \\
\text { 4. The principal has confidence in his } \\
\text { performance } \\
\text { 5. Learners feel comfortable and study hard }\end{array}$ & $\begin{array}{l}\text { Cohen, et al. (2009) } \\
\text { and Rapti (2012) }\end{array}$ \\
\hline
\end{tabular}

After all the data has been collected and the research instrument has been tested, the last thing to do is to analyze the data that has been collected, using several tests with LISREL application, including the presentation of data, the size of data concentration, the size of data distribution, Path Analysis (Normality test, multicolinierity, and linearity)

\section{Result and Discussion Descriptive Analysis}

The data show that the distribution of the answer values is spread from the minimum value of 95 and the maximum value of 150 . Based on the distribution of these values, the mean value is 123,79 , and the standard deviation is 12.603 . While the principle leadership style obtained by 59 respondents $(39,9 \%)$ stated that the leadership style variable was in the good category, and 89 respondents $(60,1 \%)$ stated it was classified as very good. That is, the achievement of the leadership style variable is categorized very well because the categorical value is dominant, so it is concluded that the leadership style is included in the very good category.

Based on research data, the distribution of the answer values spread from a minimum value of 47 and a maximum of 100 , the mean value is 73,89 , and the standard deviation (standard deviation) is 12,364 . While 23 respondents $(15,5 \%)$ explained that the teacher competency variable was in the medium category, 75 respondents $(52,7 \%)$ explained the teacher competency variable was in the good category, 47 respondents $(31,8 \%)$ explained the teacher competency variable. is in the very good category. Based on these data, it can be concluded that teacher competence is in the good category.

Based on the research data, it can be seen that the distribution of the answer values is spread from a minimum value of 19 and a maximum of 75 . Based on the distribution of these values, the average value is 48,93 , and the standard deviation is 12,775 . While as many as 60 samples $(40.6 \%)$ explained that the school climate variable was in the moderate category, 56 respondents $(37,8 \%)$ explained that the school climate variable was in the good category, 32 respondents $(21,6 \%)$ explained the school climate variable in good category. climate in very good category. The highest percentage value for the school climate variable is in the good category. So, it can be concluded that the school climate variable is in the moderate category. 
Based on the results of the study, the scores of the students' ICT test results were spread from a minimum value of 60 and a maximum of 100 , then the resulting average value (mean) was 81,0642 , and a standard deviation of 7,71016 .

The quality of student learning outcomes is known from the results of student tests. If the student's test score is more than $75(\mathrm{KKM})$, it means that the quality of student learning outcomes is good. Meanwhile, if the student's test score is less than 75, it means that the quality of student learning outcomes is not good. The learning outcomes showed that 9 students $(6,1 \%)$ were in the low category, 46 students $(31,1 \%)$ were in the medium category, 69 students (46.6\%) were in the high category, and 24 respondents $(16,2 \%)$ is in the high category. very high category. Based on these data, it is known that the quality of student learning outcomes is high.

Most of the questions on the difficulty index were in the easy category of $72,5 \%$, while the medium category was $20 \%$ and the difficult category was $7,5 \%$.

\section{Normality test}

Based on the results of the data analysis, the variables of the principal's leadership style, teacher competence, school climate, and the results of the quality of learning outcomes get a significance result of $\leq 0,05$, so the data is said to be normally distributed.

\section{Linearity test}

Based on the results of the data analysis, the variables of the principal's leadership style, teacher competence, school climate, the quality of learning outcomes, the relationship got a significance result of $\leq 0,05$, so all variables were linear. Multicollinearity test results can be seen in Table 4.

Table 4. Multicollinearity Test Results

\begin{tabular}{ccc}
\hline \multicolumn{2}{c}{ Coefficients } & \multicolumn{2}{c}{} \\
\hline Model & \multicolumn{2}{c}{ Collinearity Statistics } \\
\cline { 2 - 3 } & Tolerance & VIF \\
\hline Principal's Leadership Style &, 137 & 7,326 \\
Teacher Competence &, 169 & 5,915 \\
School Climate & 193 & 5,179 \\
\hline
\end{tabular}

In the variable of leadership style, teacher competence, and school climate there are no symptoms of multicollinearity. Hypothesis results can be seen in Figure 1.

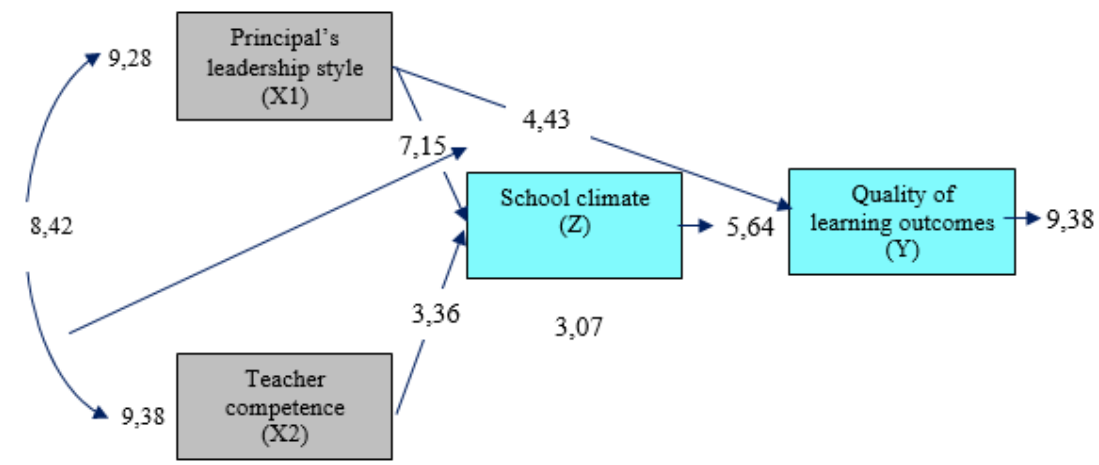

Chi-square $=0.00, \mathrm{df}=0, \mathrm{P}$-Value $=1.00000$, RMSEA $=0.000$

Figure 1. Hypothesis Test Result 
First, based on the first hypothesis, the relationship between the principal's leadership style (X1) and school climate (Z) in several vocational schools in Padang City has t count $(7,15)>t$ table $(1,96)$. Thus hypothesis 0 is rejected, hypothesis 1 is accepted. So, it can be said that the principal's leadership style (X1) has a positive and significant effect on the school climate (Z) in several vocational schools in Padang City.

The $t$ value of the leadership style variable on the quality of student learning outcomes based on the first hypothesis test is 7,15>1,96, where $\mathrm{HO}$ is rejected or $\mathrm{H} 1$ is accepted, which means that the leadership style makes a positive and significant contribution to the school climate. The analysis also shows that the effective and relative contribution of leadership style variables to school climate. The principal's leadership style is a determining factor for the quality of student learning outcomes. A good leadership style will encourage a calm and comfortable situation around the school that is conducive and motivates all school members to work together to realize the vision, mission and goals of the school, such as the quality of student learning outcomes (Sukiyanto \& Maulidah, 2020; Winarsih, 2018). The results of this study are in line with the research by (Ramadoni \& Arifin, 2016) which states that a good leadership style will form a conducive school environment that allows teachers and students to focus on carrying out teaching and learning activities.

Second, based on the second hypothesis, the relationship between teacher competence (X2) and school climate (Z) in several vocational schools in Padang City has a value of $t$ count $(3,66)>t$ table $(1,96)$. Thus hypothesis 0 is rejected and hypothesis 2 is accepted, which means that teacher competence (X2) has a positive and significant effect on school climate (Z) in several vocational schools in Padang City.

The $t$ value between the teacher competency variable and the quality of student learning outcomes is $3,36>1,96$. This means that teacher competence makes a significant positive contribution to the school climate. Competence is performance that refers to achieving goals with the aim of achieving the expected conditions. All parties in various fields and sectors of development in this globalization era are required to always improve their respective competences (Aprilda, 2012; Purwanti et al., 2014). This shows the importance of efforts to improve education both quantitatively and qualitatively on an ongoing basis, so that education can be used as a medium for building national character. So, it can be concluded that teacher competence affects the school climate. The higher the competence of teachers, the more conducive the school climate is. However, the lower the teacher's competence, the worse the school climate.

The results of this study are in line with the results of the study by (Mas, 2012), the results showed that the school climate has a partial relationship with teacher competence so that the proposed hypothesis is accepted. Teacher competence possessed by teachers can support the school climate. Teachers with good teacher competence will encourage the creation of a conducive school climate.

Third, based on the third hypothesis, the relationship between the principal's leadership style (X1) and the quality of learning outcomes (Y) in several vocational schools in Padang City has t count 8,13>t table 1.96. Thus hypothesis 0 is rejected and hypothesis 3 is accepted. So, it can be said that the principal's leadership style (X1) has a positive and significant effect on the quality of learning outcomes $(\mathrm{Y})$ in several vocational schools in Padang City.

The $t$ value between the variable leadership style on the quality of student learning outcomes is $8,13>1,96$, where $\mathrm{H} 0$ is rejected or $\mathrm{H} 1$ is accepted, meaning that the leadership style has a. significant positive contribution to the quality of student learning outcomes. Based on the analysis results also obtained the effective contribution and the relative contribution of leadership style variables to the quality of student learning outcomes. The results of this study are in line with the results of the study by (Muhani et al., 2016) the principal's leadership style is proven to have a positive and significant effect on student achievement. The better the leadership style of the principal, the student's learning achievement will increase, so that the quality of student learning outcomes increases. Principal leadership style is a complex method and process in which the principal influences teachers and employees to achieve the mission, task or target and directs the school organization based on logic. A good principal's leadership style will encourage, direct, and motivate the school community together to carry out the vision, 
mission, and goals of the school. One of the most important goals of schools is to improve the quality of student learning outcomes. If the principal's leadership style is good, the quality of student learning outcomes is also good, and vice versa.

Fourth, based on the fourth hypothesis, the relationship between teacher competence $(\mathrm{X} 2)$ and the quality of learning outcomes $(\mathrm{Y})$ in several vocational schools in Padang City has t count 5,47>t table 1,96. Thus hypothesis 0 is rejected and hypothesis 4 is accepted. Thus, teacher competence (X2) has a positive and significant effect on the quality of learning outcomes $(\mathrm{Y})$ in several vocational schools in Padang City.

The $t$ value between the teacher competency variable and the quality of student learning outcomes in the second hypothesis test is 5,47> 1,96. This means that teacher competence makes a significant positive contribution to the quality of student learning outcomes.

Besides the leadership style, another thing needed to determine the quality of learning outcomes is teacher competence. All parties in various fields and sectors of development are required to always improve their respective competencies in this era of globalization. This shows the importance of efforts to improve education both quantitatively and qualitatively that must be carried out continuously, so that education can be used as a vehicle for building national character. So, it can be concluded that teacher competence affects the quality of student learning outcomes. The results of this study are in line with the research by (Mas, 2012). In this study, it is proven that teacher competence has a positive and significant effect on student learning motivation. With competent teachers it will also make students' learning motivation good. This means that the higher the teacher's competence, the higher the student's learning motivation, so that the quality of student learning outcomes will increase. The competence of the teacher or teacher can determine the quality of student learning outcomes. Teachers who have good competence with lots of learning experience, adequate supporting facilities, good health conditions, good levels of teacher welfare, controlled principal supervision, and the number of teacher training that is followed make these teachers have better competence in teaching students. Students who are educated by teachers with good competence will make student learning outcomes good too. So, the quality of the learning outcomes is also good.

The school climate describes the condition of the school members who are happy and familiar and caring for each other. A conducive school climate is reflected in 1) Teachers feel comfortable, satisfied, and trusting, 2) Teachers do not feel pressured and pay attention to student progress, 3) Principals have confidence in their performance, and care, and 4) Students feel comfortable and sincere learning will encourage the quality of good learning outcomes (Nini, 2017).

Fifth, based on the fifth hypothesis, the relationship between school climate $(Z)$ and the quality of learning outcomes $(Y)$ in several vocational schools in Padang City has a t count value of $5,64>t$ table 1,96. Thus hypothesis 0 is rejected and hypothesis 5 is accepted. Thus, school climate $(Z)$ has a positive and significant effect on the quality of learning outcomes $(Y)$ in several vocational schools in Padang City.

The $t$ value between the teacher competency variable and the quality of student learning outcomes is 5,64>1,96. This means that teacher competence has a positive and significant contribution to the quality of student learning outcomes (Shobron \& Suyanto, 2016). The school climate is conducive to school principals, teachers and students who have a fighting spirit in carrying out their respective duties and responsibilities, principals and teachers have a work ethic and students have learning ethics, little violations of discipline and school discipline both by instructors and by students will affect the quality of learning outcomes which is reflected in the cognitive, affective and psychomotor abilities of students both.

Sixth, based on the sixth hypothesis, the relationship between the principal's leadership style (X1) through the school climate (Z) with the quality of learning outcomes in several vocational schools in Padang City has a value of $4,43>t$ table 1,96. Thus hypothesis 0 is rejected and hypothesis 6 is accepted. So, it can be stated that the principal's leadership style (X1) through the school climate (Z) has a positive and significant effect on the quality of learning outcomes $(Y)$ in several vocational schools in Padang City. 
The $t$ value between the variable leadership style and the quality of student learning outcomes through the school climate is $4,43>1,96$. This means that the leadership style makes a significant contribution to the quality of student learning outcomes through school science.

School climate describes the condition of school members in a happy and familiar or caring state. The close relationship with the school climate occurs because of the good relationship between the principal and instructors, as well as between teachers and students (Hakim \& Sarbiran, 2004; Suhendro, 2012). School climate like this is an important aspect that supports the success of a learning process so that the quality of learning outcomes is good. In line with research by (Arifin et al., 2018) which states that a good leadership style is supported by a good school climate with good teacher behavior and principal behavior, a high level of teacher comfort, a high level of confidence in the performance of the principal, and the level of comfort and comfort of students. the seriousness of students to learn will make good quality student learning outcomes too. The better the leadership style that is supported by a good school climate, the better the quality of student learning outcomes. However, the worse the leadership style supported by a bad school climate, the worse the quality of student learning outcomes.

Seventh, based on the seventh hypothesis, the relationship between teacher competence (X2) through school climate $(Z)$ and the quality of learning outcomes $(Y)$ in several vocational schools in Padang City has $t$ count 3,07>t table 1,96. Thus hypothesis 0 is rejected and hypothesis 7 is accepted. Thus, teacher competence $(X 2)$ through the school climate $(Z)$ has a positive and significant effect on the quality of learning outcomes $(Y)$ in several vocational schools in Padang City.

The $t$ value of the teacher competency variable and the quality of student learning outcomes through the school climate is $3,07>1,96$. This means that teacher competence makes a significant contribution to the quality of student learning outcomes through school science. Teacher competence is teacher performance which refers to achieving goals as a whole towards the expected conditions. While the school climate can be interpreted as a situation around the school and a calm and comfortable atmosphere that is suitable and conducive to learning that can improve learning achievement (Arsil et al., 2018; Nini, 2017). Intimate relationships in the school climate occur because of a good relationship between the principal and teachers, as well as between teachers and students (Aguswara \& Rachmadtullah, 2017; Arifin et al., 2018). Good professional teacher competition supported by a good school climate will make the quality of student learning outcomes also good. In line with research by (Mas, 2012) which proves that there is a significant relationship between professional and personal competence of instructors and student motivation in the teaching and learning process. While (Suhendro, 2012) states that there is a positive influence of school climate on student interest. Thus, the more conducive the school climate is, the higher the student's interest in learning. Thus, the competence of teachers with the support of a good school climate will make the quality of student learning outcomes good. Good teacher competence with lots of teacher learning experience, adequate supporting facilities, good teacher health conditions, high levels of teacher welfare, good principal supervision, and the number of teacher training courses supported by a good school climate with the behavior of teachers and The principal, a high level of teacher comfort, a high level of confidence in the performance of the principal, and a high level of student comfort, and serious student learning will make the quality of student learning good. This means that the higher the competence of teachers who are supported by a good school climate, the better the quality of student learning outcomes, however the lower the competence of teachers supported by a bad school climate, the worse the quality of student learning outcomes.

\section{Conclusion}

Based on the research results, it can be concluded that the principal's leadership style, teacher competence has a significant effect on the climate of SMK in Padang. The leadership style of the principal has a significant effect on the quality of Vocational School learning uutcomes in Padang City and the competence of teachers has a significant effect on the quality of vocational learning outcomes in Padang City. 


\section{References}

Aguswara, W. W., \& Rachmadtullah, R. (2017). Pengaruh Gaya Kepemimpinan Kepala Sekolah Dan Iklim Organisasi Dengan Kinerja Guru Pendidikan Anak Usia Dini. JPUD - Jurnal Pendidikan Usia Dini, 11(2), 369-385. https://doi.org/10.21009/jpud.112.14

Aprilda. (2012). Pengaruh Kompetensi Terhadap Prestasi Kerja Pegawai ( Studi pada Bagian Pengelolaan Keuangan Balai Pengembangan Pendidikan Nonformal dan Informal Regional I Medan ) Pemerintah Provinsi Sumatera Utara. Jurnal Administrasi Publik, 3(2), 181-206. https://doi.org/10.31289/jap.v2i2.1371

Arifin, R. B. M., Teh, K. S. Bin, Muhamad, N., \& Amrullah. (2018). Pemikiran Ibnu Khaldun dalam Strategi Pelaksanaan Iklim Dini Di Sekolah. Pedagogia : Jurnal Pendidikan, 7(2), 137-144. https://doi.org/10.21070/pedagogia.v6i1

Arsil, A., Yantoro, Y., \& Sari, R. (2018). Analisis Iklim Sekolah dalam Mendukung Proses Pembelajaran di Sekolah Dasar. Journal of Inherited Metabolic Disease, 3(1), 39-56. https://doi.org/10.22437/gentala.v3i1.6753

Aryani, W. D. (2014). Peningkatan keaktifan dan hasil belajar IPS melalui PAKEM dengan bantuan media pada siswa kelas VIIIA SMP Negeri 1 Kandeman Batang tahun pelajaran 2013/2014. Jurnal Forum IImu Sosial, 41(1), 103-124. https://doi.org/10.15294/fis.v41i1.5397

Creswell, J. W. (2008). Research Design, Pendekatan Kualitatif, Kuantitatif, dan Mixed, Edisi Ketiga. Bandung: Pustaka Pelajar.

Djafar, H. (2017). Model Kepemimpinan Dalam Pembinaan Karakter Peserta Didik Di Smk Negeri Labuang Kabupaten Polewali Mandar. Idaarah: Jurnal Manajemen Pendidikan, 1(2), 191-199. https://doi.org/10.24252/idaarah.v1i2.4263

Djafri, N. (2015). Pengaruh Gaya Kepemimpinan, Empati Dan Motivasi Terhadap Budaya Organisasi (Studi Kasus Terhadap Kepala Sekolah Dasar Kota Gorontalo). Jurnal Manajemen, 19(1). https://doi.org/http://dx.doi.org/10.24912/jm.v19i1.105

Hakim, H., \& Sarbiran, S. (2004). Iklim Belajar dan Iklim Praktik serta Produktivitas Belajar ditinjau dari Aspek Kepemimpinan Kepala Sekolah dalam Konteks Pendidikan Sistem Ganda. In Jurnal Penelitian dan Evaluasi Pendidikan (Vol. 3, Issue 4). https://doi.org/10.21831/pep.v3i4.2080

Hapsari, O., Hariyadi, S., \& Prihastuty, R. (2014). Pengatuj. Intuisi. (JURNAL ILMIAH PSIKOLOGI), 6(1). https://doi.org/10.15294/intuisi.v6i1.11913

Lestari, I. (2018). Penerapan Metode Pembelajaran Diskusi Dan Resitasi Dalam Meningkatkan Hasil Belajar Pendidikan Agama Hindu Siswa Kelas Iv Sd Negeri 2 Tumbu Karangasem. Jurnal Penjaminan Mutu, 4.

Mas, S. (2012). Hubungan Kompetensi Personal Dan Profesional Guru Dengan Motivasi Belajar Siswa Di SMKN 2 Kota Gorontalo. Jurnal Pendidikan Dan Pembelajaran (JPP), 19(2), 212-219.

Muhani, M., Imron, A., \& Kusmintardjo, K. (2016). Kepemimpinan Kepala Sekolah Dasar Di Daerah Terpencil (Studi Multi Kasus Di Sdn 2 Bakalan Dan Sdn 2 Kepyar Purwantoro Kabupaten Wonogiri). Jurnal Pendidikan: Teori, Penelitian, Dan Pengembangan, 1(8), 1464-1472. https://doi.org/10.17977/JP.V118.6616

Nini, A. (2017). Pembinaan Iklim Sekolah K-7 Sebagai Upaya Meningkatkan Efektivitas Belajar: Best Practices. Cendekia: Jurnal Kependidikan Dan Kemasyarakatan, 13(2), 133-140. https://doi.org/10.30957/cendekia.v13i2.601

Purwanti, K., AR, M., \& Yusrizal, Y. (2014). Kepemimpinan Kepala Sekolah Dalam Meningkatkan Kompetensi Guru Pada Smp Negeri 2 Simeulue Timur. Jurnal IImiah Didaktika, 14(2), 390-400. https://doi.org/10.22373/jid.v14i2.510 
Ramadoni, W., \& Arifin, I. (2016). Kepemimpinan Kepala Sekolah Dalam Upaya Peningkatan Kinerja Guru (Studi Multi Kasus Di Paud Islam Sabilillah Dan Sdn Tanjungsari 1 Kabupaten Sidoarjo). 1500-1504.

Shobron, S., \& Suyanto, S. (2016). Kinerja Guru Bersertifikasi Dalam Meningkatkan Manajemen Mutu Pendidikan Di Madrasah Ibtidaiyah Muhammadiyah Sudung Kedungtuban Blora Tahun 2015. Profetika: Jurnal Studi Islam, 17(01), 57-67. https://doi.org/10.23917/profetika.v17i01.2100

Sugiyono. (2013). Metode Penelitian Kuantitatif, Kualitatif dan R\&D. Bandung: Alfabeta.CV.

Suhendro, H. (2012). Iklim Organisasi Sekolah, Kecerdasan Emosional Guru, Dan Pengetahuan Teknologi Informasi Dengan Profesionalisme Guru Smk. Teknologi Kejuruan, 32(1).

Sukiyanto, \& Maulidah, T. (2020). Pengaruh Gaya Kepemimpinan Kepala Sekolah dan Budaya Organisasi terhadap Motivasi Guru dan Karyawan. Jurnal Pendidikan Edutama, 7(1), 127. https://doi.org/10.30734/jpe.v7i1.874

Sumantri, R. F. (2012). Kompetensi Pengelolaan Pembelajaran, Kecerdasan Interpersonal, Komitmen, Dan Kepuasan Kerja Guru SMK. Jurnal IImu Pendidikan, 18(1), 30-35.

Winarsih, S. (2018). Gaya Kepemimpinan Kepala Sekolah dalam Meningkatkan Kinerja Guru. International Conference of Moslem Society, 2, 95-106. https://doi.org/10.24090/icms.2018.1864

Yudiaatmaja, F. (2017). Kepemimpinan: konsep, teori dan karakternya. Media Komunikasi FPIPS, 12(2). http://dx.doi.org/10.23887/mkfis.v12i2.1681 